\title{
Demantoid from the Telyansky Klyuch deposit (Middle Urals) - is the place of the first discovery in the Urals
}

\author{
Sergey Yur'evich KROPANTSEV ${ }^{1,2^{*}}$
}

${ }^{1}$ LLC "Berezovskiy rudnik", Berezovskiy, Sverdlovskaya oblast', Russia

${ }^{2}$ The Zavaritsky Institute of Geology and Geochemistry of the Ural Branch of RAS, Ekaterinburg, Russia

\section{Annotation}

The relevance of the work is due to the need to study the Ural gems, including those discovered in the Urals. This is important not only from a scientific point of view, but for the history of science and the development of geological tourism in our region as well.

Purpose of the work: study of the chemical composition of demantoid from the Telyansky Klyuch deposit, which is the site of the first find of this gem in the Urals.

Research methodology. Demantoid (green jewelry andradite) was washed by the author in the Telyansky Klyuch gold placer; the quantitative analysis of the chemical composition of garnet was performed using the JXA-733 X-ray electron probe microanalyzer.

Results. A historical study of the sites of finds of demantoids in the Middle Urals was carried out. It was established that precious garnet was found not in placers of the Bobrovka river located south of Nizhny Tagil, but in the gold placer of the Telyansky Klyuch to the north of Nizhny Tagil. Microprobe analysis of individual demantoid crystals showed that garnets with different green color saturation according to the main components are andradites with average contents: $\mathrm{CaO}-33,18 \% ; \mathrm{Fe}_{2} \mathrm{O}_{3}-30,74 \% ; \mathrm{SiO}_{2}-35,02 \%$ (for 6 analyzes). The feature of the chemical composition of Telyansky demantoids is the absence or insignificant amount of aluminum impurity in them - not more than $0.02 \% \mathrm{Al}_{2} \mathrm{O}_{3}$, which is practically at the level of microprobe analysis sensitivity for this element. The amount of chromium varies from $0.02 \% \mathrm{Cr}_{2} \mathrm{O}_{3}$ in a light green demantoid to $0.5-0.74 \% \mathrm{Cr}_{2} \mathrm{O}_{3}$ in green and bright green andradites.

Conclusions. The place of the first find of low-impurity and chromium-containing andradites in the Urals with the name of "diamantoite" (proposed by N. G. Nordenskiöld ) is the Telyansky Klyuch gold deposit on the East Tagil dunite-harzburgite massif in the Middle Urals.

Keywords: garnet, andradite, demantoid, serpentinites, Telyansky Klyuch, Middle Urals.

\section{Introduction}

Demantoid is one of the most remarkable gems of the garnet family. Golden-green color and bright shine, along with transparency and brilliant lustre of some varieties of jewelry demantoid, make them look like the rarest green diamond in the wild. The demantoid called "Ural chrysolite" became a jewelry stone for the first time in Russia, the Urals. Here, in the Urals, there are deposits of the world's unrivaled jewelry demantoid. In this regard, the demantoid is a real Ural gem.

Recently, interest in the Ural demantoid has grown surprisingly. In the Urals, the world's largest indigenous deposit of this jewelry variety of andradite, Poldnevskoye, is being developed. Both in Russia and abroad, scientific papers on the Ural demantoid are published. However, most of the works are full of different interpretations regarding the history of the subject of study. There is still no consensus about the way famous mineralogist N. G. Nordenskiöld proposed a name for the demantoid. The place of the first find of a "diamond-like garnet" in the Urals is forgotten. However, the original demantoid of N. G. Nordenskiöld, or the flawless demantoid, is still poorly understood.

Historical essay on the demantoid from the Nizhny Tagil district
It is generally accepted that the demantoid was first found in the gold-platinum placer of the Bolshaya Bobrovka (Elizavetinskaya) river, a tributary of the Tagil River [1]. Geologically, the Bobrovskaya placer is located in the western marginal part of the Nizhny Tagil platinum-bearing clinopyroxenite-dunite massif in the Middle Urals.

Demantoid-bearing placers of the Bolshaya Bobrovka River with its tributary (the Malaya Bobrovka stream) adjoined the Pavlovsky platinum mine of the Demidovs. According to the data of G. Koltovsky, Pavlovsky mine "was opened in 1840 by an exploration team sent by Ivan Belov, a mine watchman..." [2]. More than half a century later, in May 1893, development of demantoids began along the placers of the Bolshaya Bobrovka River and the Malaya Bobrovka stream [3]. Soon, the largest placer of demantoids was designated on the map of the Urals later known as the Bobrovskoye deposit of demantoids. Apparently, this was the main reason to consider the richest demantoids of Bobrovskoye as "first ones in the world". But, as it turned out, the first demantoids were found not in platinum, but in a gold placer.

In the early 1830s, the Nizhne-Tagil mountain district of the Demidovs was the main supplier of gold in the Urals. It was 
very famous for platinum mining. Some scientists associated the possibility of finding diamonds in the Urals with placer deposits. They expected unprecedented diamonds in Nizhny Tagil. In the late $1830 \mathrm{~s}$, when almost all gold and platinum mines were discovered and operated around some plants of Nizhny Tagil, where placers of demantoids became known later, there was some news of the find called "Nizhny Tagil diamonds".

In 1842, The Russian Mineralogical Society celebrated its 25 th anniversary. The anniversary volume of the Proceedings of the Russian Imperial Society of General Mineralogy based in St. Petersburg (Schriften ...) contained the History of Society written by its secretary, Georgiy Astafievich Pott. The whole work was published in German. It was a kind of comprehensive report on the activities of the St. Petersburg Mineralogical Society. The need for such a reporting form was explained by the rarity of the publication. The previous first volume of the works of society was published in 1830 (before the discovery of the Emerald Mines, phenakite, and alexandrite in the Urals). In the anniversary volume of "Schriften ..." all the main news of the geological and mineralogical nature over the past long period was gathered together.

Mentioning platinum from the Nizhne-Tagil placers, G. A. Pott writes: "This metal, which is found in gold-bearing placers in Siberia, in addition to gold, is accompanied by: osmiridium, magnetic iron ore, chromium iron ore, rutile, brown iron ore, epidote, garnet, rock crystal in individual crystals, or on the rock. Platinum is accompanied by: fragments of quartz, jasper, serpentinite, diorite, greenshist and greenschist porphyry. It should be mention about small polyhedral crystals. They are mostly transparent, yellowish white, oily green, brownish yellow, and least often they have beautiful emerald green color. They have brilliant lustre on their surface, which is close to an oily one. These crystals were considered diamonds and were sent from Nizhne-Tagilsk to the Demidov office in St. Petersburg because they had a great resemblance to those that were found in the Perm province in the possession of the city of Butero, but chemical analysis did not happen. According to the Mineralogical Society, they should be assigned to the system of chrome garnets or uvarovite. In addition, we also note that the Mineralogical Society has a piece of platinum, which has a beautiful green uvarovite in its depth" [4].

Earlier, speaking of the discovery of the given uvarovite by G. I. Hess in the Urals, the speaker noted that this "beautiful and rare mineral" was also found in 1839 in the Nizhne-Tagil platinum mines [4].

What relation could green and yellow "polyhedral crystals of garnet with brilliant lustre" have to do with real uvarovite? Uvarovite is a new emerald green garnet was discovered in 1832 by German Ivanovich Hess (1802-1850). The mineral was first found in the Bisertsky factory of Countess Polie Butero in the Urals. It took its name in honor of the President of the Russian Imperial Academy of Sciences and Honorary Member of the Imperial Mineralogical Society S. S. Uvarov (1786-1855). In 1832, G. I. Hess announced: "Judging by the reaction in front of the soldering tube, uvarovite represent the same relationship as garnet; it has greater hardness and is more difficult to melt. A thin fragment of a mineral, being clipped into platinum tweezers, does not melt at all with the strongest heat and does not change either its color or its degree of transparency". And only nine years later, in 1841, A. Komonen made a complete chemical analysis of the mineral for the first time and determined that uvarovite from the Bisertsky plant in the Urals belongs to calcareous garnet [5].

The first find of polyhedral crystals "similar to uvarovite" in the Nizhne-Tagil placers occurred in 1839, or at the time of the formation of a general idea of scientists about the present uvarovite of G. I. Hess. During the absence period of a full chemical analysis of the calcareous garnet, mineralogists could suppose that uvarovite could be not only emerald green, but yellow as well.

Assuming that green garnet belongs to the "system of chrome garnets" in intergrowth with platinum from the Nizhne-Tagil placers, Russian scientists are one step away from a new discovery. However, as from 1842, over the course of a century, almost all of these garnets were mistaken for "uvarovites". It was not until 1949 that based on accurate studies, A. G. Betekhtin determiined that the so-called "uvarovites" from dunites of the Nizhny Tagil platinum-bearing massif in the Urals belong to high-chromium andradite [6]. At the same time, it was considered proven that yellow, yellow-green and emerald-green garnets with a bright, almost brilliant lustre from the Nizhny Tagil placers are demantoids (andradites).

Obviously, in 1842, G. A. Pott, a secretary of the St. Petersburg Mineralogical Society, in his report on the activities of the society (for a decade) mixed together dark green chromandradites in intergrowth with platinum, and brownish-yellow, yellow-green and bright green demantoids (andradites) from the Nizhny Tagil gold and platinum placers. But during that period, the term "andradite" did not exist yet. In the nomenclature of minerals, all emerald green, green and yellow-green garnets belonged either to uvarovite or to calcium aluminium garnet. In order to distinguish calcium-iron garnet (andradite) from refractory uvarovite, it is enough to test it in the flame of a soldering tube, where it is relatively easily fused into a magnetic cupel. However, in 1839-1842, the fusibility tests of the alleged "uvarovites" from the Nizhny Tagil placers, as can be seen, have not been done.

Erroneous identification by scientists of yellow and yellow-green crystals of garnet with brilliant lustre with uvarovite could not have a significant impact on the use of the mineral as a jewelry stone. The further fate of the "diamond-like uvarovites" largely depended on the will of its seeker and owner.

But the will of ordinary developers of the Nizhny Tagil gold and platinum was constrained by tough serfdom. For the plant manager M. D. Danilov, a new sensation - the discovery of "diamonds" - did not work. The owner himself - the cadet chamber junker Anatoliy Nikolayevich Demidov, far from the Ural factories - was not interested in the small crystals of "uvarovites" in practical terms. The pursuit of platinum nuggets and the richest gold continued in Nizhny Tagil.

But still, thanks to the tradition laid down by the predecessors of A. N. Demidov, the alleged "uvarovites" were not completely forgotten. They became the centre-piece of the Nizhny Tagil factory museum of the Demidovs. Here they remained "similar to the yellow and green Ural diamonds", until the famous scientist N. G. Nordenskiöld who arrived in Nizhny Tagil did not propose his own name for this garnet - "diamantoite".

Nils Gustaf Nordenskiöld (Swed. Nils Gustaf Nordenskiöld, 1792-1866, Fig. 1) is a descendant of the Swedish noble family, Finnish and Russian mineralogist at the same time, a full member of the Imperial St. Petersburg Mineralogical Society, 


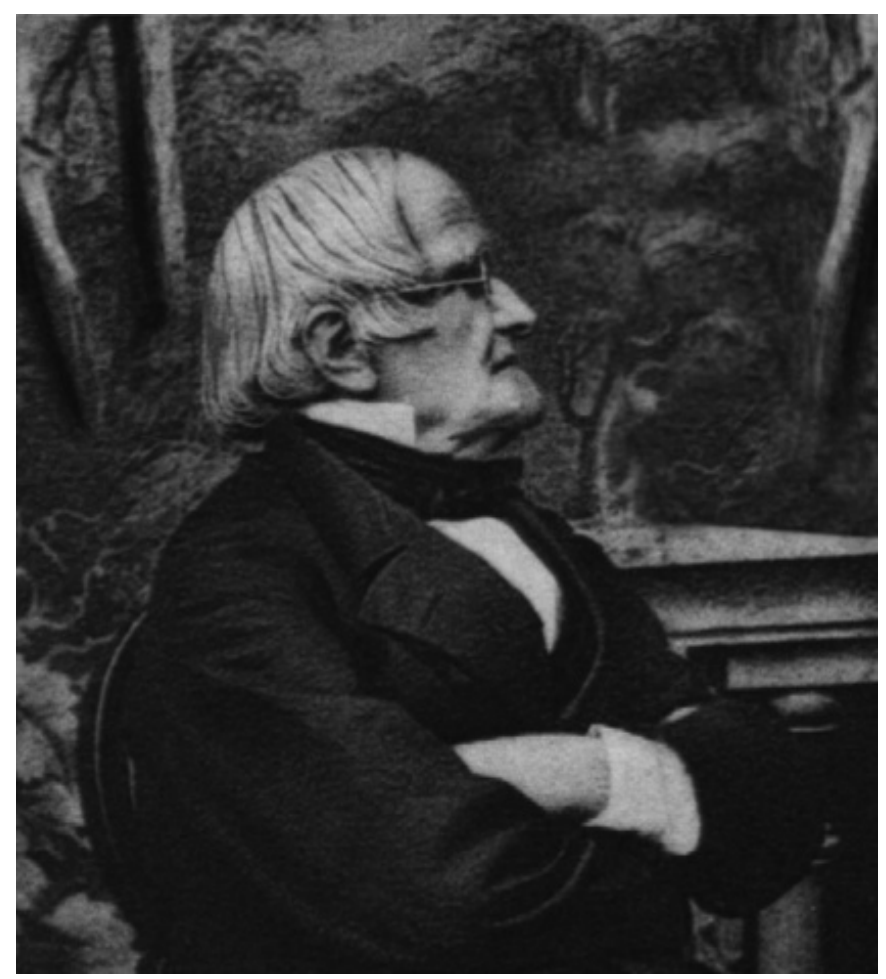

Figure 1. Nils Gustaf Nordenskiöld (1792-1866). Рисунок 1. Нильс Густав Норденшельд (1792-1866).

and the author of the names "phenakite" and "alexandrite". In 1840 , he showed one of his many talents in the field of metallurgy. He invented the so-called "wet method" of processing copper ores. The essence of the method was crushing ore to a certain size, followed by chemical enrichment and smelting in a reverberatory furnace. The Nordenskiöld method was first used at the Statberg plant in Westphalia [7].

By the early 1850s, the reserves of copper ore of the Mednorudyanskoye deposit, the largest in the Urals, were depleted. The Vyiska copper-smelting plant in Nizhny Tagil increasingly received miserable ores, the so-called "copper fines", the smelting of metal from which, according to old technology, became unprofitable. In connection with the unsettling situation in the strategically important branch of metallurgy, Aurora Karlovna Demidova (in the second marriage of Karamzin) took possession of the Nizhne-Tagil plants in the Urals as a co-owner after the death of her husband P. V. Demidov (1798-1840) and repeatedly tried to restore the smelter production. To this end, foreign experts from Baden and Guttenberg were invited to the Urals. However, all attempts were unsuccessful and brought nothing but enormous loss. In 1853 (when the Eastern War of 1853-1855 began, with its main actions in the Crimea during the defense of Sevastopol in 1854-1855), Aurora Karamzina, the St. Petersburg beauty, refused the trend to invite "experts" of various kinds from abroad. She turned to Russian scientists for help, and therefore invited N. G. Nordenskiöld to the Urals. His main result was the commissioning of new copper-smelting furnaces at private and state factories. Since 1856, smelting of copper began in the Nordenskjold furnaces at the Vyisk Demidov smelter and the state-owned Bogoslovsky smelter and much cheaper than before.

According to the correspondence of the Nizhne-Tagil Plant Management with the Main Directorate of the Demidov factories in St. Petersburg, N. G. Nordenskiöld together with his son Adolf Eric arrived in Nizhny Tagil on December 12, 1853. The father immediately started working at the Vyiska smelter. His son was a graduate of the Imperial Alexander University in Helsinki, so he began studying the mineralogy of the Mednorudyansk deposit. The Nordenskiölds stay in the Urals turned out to be short. February 20, 1854, Nils Nordenskiöld completed his experiments on the enrichment of "copper ore" at Vyisky plant. In March of 1842, the Nordenskiölds left Nizhny Tagil and returned to Helsingfors (Helsinki) [7].

The period of their attendance in Nizhny Tagil coincided with one remarkable event. In 1853, the Prince of San Donato, Anatoly Nikolayevich Demidov, the president of the Imperial Mineralogical Society, wished to have "exhibits from the antediluvian world that could be found in the interior of the Nizhny Tagil district". In the Nizhny Tagil Factory Museum, new collections have appeared. "Three Kingdoms of Nature: $A$ - mineral reign, $B$ vegetable kingdom, $C$ - animal kingdom". Among the authors of those collections were two persons: Krieger, a mineral pharmacist, and A. M. Yanushkevich, a factory librarian and gardener. In 1854, the mining technician Fedor Chernonogov managed the collection of the Mineral Kingdom Collections [7].

In the winter of 1853-1854, all the gold and platinum mines of the Nizhne-Tagilsky district of the Demidovs were out of service (demantoid placers will become known in the future). In the Nizhny Tagil factory museum, N. G. Nordenskiöld had the chance to see "diamonds similar to uvarovite", which came not only from platinum, but from gold placers as well. The famous scientist, who was interested in green and the socalled "yellow uvarovites", was given a batch of colored crystals and rounded grains of mineral for further research by the owners of the "Mineral Kingdom Collection".

After examining museum specimens of "diamonds-uvarovites", Nordenskiöld came to the conclusion that that was a special kind of garnet, which he proposed to call "Diamantoite" from the German Diamant - "diamond" or "diamond-like". According to A. E. Nordenskiöld, this name was associated with the shape of crystals and the brilliance of the mineral [8]. In its original form, the name of the mineral was preserved thanks to the museum catalog of V. V. Nefediev [9].

Nordenskiöld proposed a name for the demantoid in German transcription breaking with tradition of mineralogists to give names to fossils according to their special properties pursuant to the Greek dictionary and paying scientists' respects to the history of the origin of science in ancient Greece. In that case, Nordenskiöld made an exception for a new Ural mineral from Nizhny Tagil placers. The German root of the name "diamantoite" contained a clear indication of the history of a "diamond-like garnet" finding in Russia in 1842. "Diamonds-uvarovites of A. N. Demidov" was first mentioned in the "Schriften ..." of the St. Petersburg Mineralogical Society in German because German language dominated among the Russian mineralogists. In general, the name "diamond-like garnet" did not stand out from the general series of names of the Ural minerals and their varieties proposed at different times by N. G. Nordenskiöld: Phenacite, Alexandrite ... Diamantoite.

In 1854, little was known about the "calc-iron garnet" (calcium-iron garnet, andradite now). In the 4th edition of System of Mineralogy by James Dwight Dana (1813-1895), almost all 
the information known by then about minerals of the garnet group was collected. A subspecies of garnet consisting of silicates of iron and lime was called "iron-lime garnet". It included partially allochroite, aplom, melanite and usual garnet. The color of varieties was determined from dark red, orange brown and brown to brownish black, grayish black and velvet black. Gloss - from dull to resinous (colophonite) and semi-metallic (pyrenite) [10].

In 1854, only topazolite among all the known minerals of the garnet group from the Ala Valley in Mussa Alps (Italy) resembled demantoids in its description. But in the System of Mineralogy by Dana topazolite belonged to the kind of calcium aluminium garnet. In the nomenclature of garnets, it was between succinite and rumyantsevite - amber to brownish calcium aluminium garnet [10].

N. G. Nordenskiöld knew the properties of garnets well and had sufficient knowledge of how to diagnose them. As early as 1820, he discovered rumyantsevite (cinnamon stone). Since 1852, he was engaged in the study of ivaarite - a new kind of calcareous garnet of black color containing titanium (shorlomite). Nils Nordenskiöld first described the physical properties of ivaarite (shorlomite) and the product of its melting in the flame of a soldering tube.

N. G. Nordenskiöld was one of the first Russian mineralogists who introduced the use of microscope. When using it, due to the isotropic properties of garnet, the demantoid can be easily distinguished from olivine, a mineral similar to it in relative hardness, fracture, and color of yellow-green grains devoid of clear crystalline planes. Being a student of Friedrich Moos, a famous crystallographer, Nordenskiöld in the form of crystals of the demantoid could accurately attribute the mineral to a group of garnets, and its belonging to the ferruginous garnet was easily established due to the product of the mineral melting in the flame of a soldering tube.

At that time, when classification in mineralogy was just in its infancy, and all new minerals were mainly given in the form of a list in alphabetical order, N. G. Nordenskiöld proposed creating a unified mineralogical systematics based on the atomic and chemical structure of minerals. In 1842, a book by Nordenskiöld was published in the Mining Journal on the systematics of minerals [11]. So, offering the name for the demantoid, N. G. Nordenskiöld as an expert in the actual range of minerals unmistakably separated the "diamond-like garnet" not only from bright green uvarovite, but from all kinds of known yellow and green calcium aluminium garnets.

The term "diamantoite" proposed by N. G. Nordenskiöld implies a wide range of the latest kinds of calcareous-ferruginous garnet in all shades of yellow and green. The name for the hypothetical calcareous-ferruginous garnet - "andradite" - had not yet appeared in mineralogy by that time. The name "diamond-like" itself claimed a common name for the group, as it reflected the main property of the low-impregnated calcareous garnet - its highest refraction index among other transparent garnets and bright luster associated with it.

It remained to make the discovery publicly available, but Nils Nordenskiöld wrote not a one scientific paper about the demantoid. He divided his grains and mineral crystals into two small lots and sent one to the Geological Museum of the St. Petersburg Mining Institute [12], and the second to the Mineralogy office of St. Petersburg University [13]. The scientist ac- companied his parcels with notes, where he indicated the name of the garnets proposed by him, as well as the place of his find. Possibly, N. G. Nordenskiöld decided to give the right to his colleagues to correct a long-standing mistake themselves. Only when the scientists of the St. Petersburg Mineralogical Society recognized their previous erroneous assumption, he could write a full-fledged scientific paper "On Diamantoite" from the point of view of the history of the discovery of this mineral.

Until 1871, in the "Catalogue of the Mineralogical Collection of the Museum of the Mining Institute" in St. Petersburg compiled by mining colonel V. V. Nefediev, there was only one batch of samples of the demantoids sent by N. G. Nordenskiöld. Here it is written by the number $H-194^{3}$ ) / 1: "Diamantoite (in single grains). From gold placers, near the Nizhne-Tagil plant, Perm province" [9]. The name of the gold placer, where the first demantoids came from, has been preserved thanks to the work of the custodians (conservators) of the museum collection of the Department of Mineralogy of St. Petersburg University Mikhail Savvich Tarasov and Nikolai Ivanovich Zhdanov, as well as the head of the Department of Mineralogy, Associate Professor Mikhail Vasilyevich Erofeev. Until 1881, the collection of the Department of Mineralogy included a batch of crystals and grains of demantoids sent by N. G. Nordenskiöld. It was reported, all samples of the mineral came "from the Telyansky Klyuch, near the village of Kamennaya Telyany, in the district of Nizhny Tagil factories in the Urals" [13].

The gold mine along the Telyansky Klyuch stream (Fig. 2) in the Tagil river system was found in 1824 and was developed until 1829, and then from 1830 to 1851 inclusive [2]. By the time of the first arrival of N. G. Nordenskiöld in Nizhny Tagil in December 1853, the Telyansky placer was completely abandoned, but not forgotten. Back in 1824, the largest gold nugget weighing $2 \mathrm{~kg} 457 \mathrm{~g}$ was found here in the Nizhny Tagil district. Large and unique (bizarrely shaped) nuggets were delivered in kind for the office of N. N. Demidov. In this regard, the manager of the Nizhne-Tagil factories M. D. Danilov paid special attention to the development of the Telyansky placer. Its second and longest development period (since 1830) coincided with the onset of the "diamond rush" that broke out in the Urals following the discovery of diamonds in the Krestovozdvizhenskie goldfields. According to a long tradition of Demidov, samples of unusual minerals came to the Nizhny Tagil factory museum.

When listing in chronological order the gold and platinum mines of the Nizhne-Tagil district of the Demidovs in the Urals, where later demantoids became known in the placer accumulation, we can obtain the following: 1) Telyansky gold mine (1824); 2) Studeno-Klyuchevskaya gold-platinum mine (1833); 3) Pavlo-Anatolyevsky platinum mine (1834); 4) Pavlovsky platinum mine (1840). By 1842, at the time of the first report on "diamonds-uvarovites" of A. N. Demidov, all the main demantoid deposits in the vicinity of the Nizhny Tagil factories were discovered. The Pavlovsky mine, the richest in demantoids, is the last one in the series of discovery of placers.

The first studies of the chemical composition of the demantoid began only in 1867. A year later, as the founder of the mineralogy of Finland and one of the glorious creators of the Golden Age of Russian Descriptive Mineralogy N. G. Nordenskiöld joined the angels.

In 1867, the teacher of practical mineralogy of the Mining Institute and the curator of the Geological Museum 


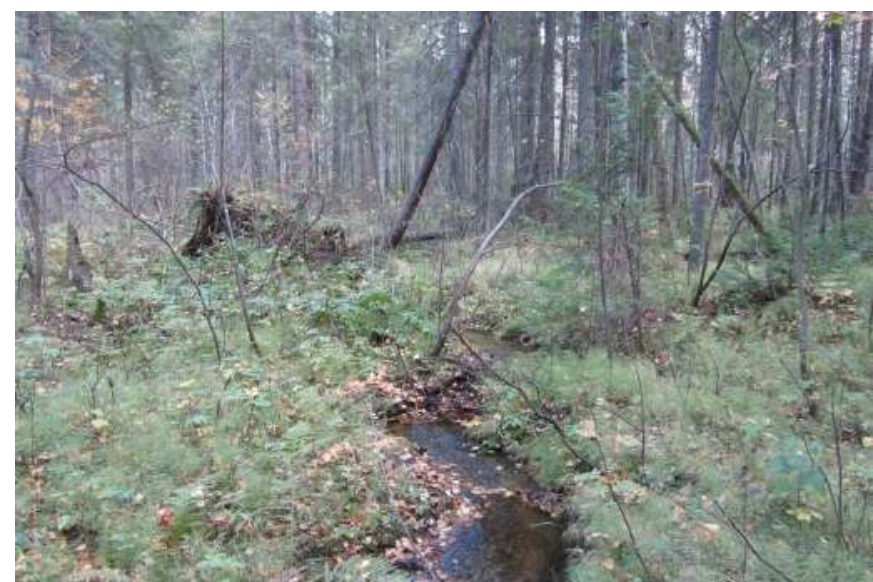

Figure 2. The site of the former Telyansky gold mine (developed in 1824-1851). The Vostochno-Tagilskiy massif of hyperbasites. Middle Urals. Author's photo.

Рисунок 2. Участок бывшего Телянского золотого прииска (разработки 1824-1851 гг.). Восточно-Тагильский массив гипербазитов. Средний Урал. Фото автора.

V. V. Nefediev, on the basis of the results of a study of demantoids at the chemical laboratory of the Mining Institute, classified them as a "variety of olivine," while retaining the name of the mineral proposed by N. G. Nordenskiöld. Nefediev did not write a scientific paper about the demantoid, but orally presented the results of the study of an imaginary "diamond-like olivine" to the librarian of the Mining Institute D. Planer - the compiler of the "Collection of newly discovered and newly explored minerals in recent times" [12].

In 1870, the Secretary of the St. Petersburg Mineralogical Society, Professor Pavel Vladimirovich Eremeev, investigated the qualitative composition of demantoids using the soldering tube method and classified the mineral as an "extraordinary variety of calcium aluminium garnet". At the same time, he gave the first and the most complete description of the physical properties of the Nordenskiöld demantoids. It is very remarkable that P. V. Eremeev ends his report with these words: "Although ... the properties of the demantoid also make it rank among the varieties of calcareous-alumina garnet ... the name given to the mineral by N. Nordenskiöld should be preserved in science, because the strong brilliant lustre, the special purity and brightness of the colors quite distinguish the demantoid from ordinary calc-alumina garnets" [14]. In late 1879, at the meeting of the Mineralogical Society, P. V. Eremeev reported on a re-study of Nordensköld demantoids using the soldering tube method and determined that the mineral belongs to calcareous garnet (andradite) [15].

In 1881, a quantitative analysis of the chemical composition of Nordensköld's demantoids was performed by P. D. Nikolaev, a laboratory assistant at the St. Petersburg Mining Institute. He confirmed the conclusion of P. V. Eremeev that garnet named "demantoid" belongs to andradite [13].

Over time, the original name "diamantoite" of N. G. Nordensköld was first transformed into "Demantoite" [12], and then into "Demantoid" [14] as a result of oral reports of the first researchers of the chemical composition of the mineral. In 1904, "diamond-like garnet" was included in the System of Mineralogy by E. S. Dana [16] with the name already familiar to mineralogists, but with a completely distorted one.
The involuntary replacement of the historically-grounded German root "diamant" with the so-called "Dutch" root "demant" in the demantoid name in 1867 (before it became a new jewelry stone) left its mark. Later, in the mid-1870s, in the vicinity of Poldnevaya in the south of the Middle Urals, a new occurrence of jewelry andradite was discovered. Demantoid was considered to be a gemstone. That was one of the reasons for the stubborn rejection by the Ural peasants-prospectors, gem cutters and jewelers of the "right" (from the point of view of official science) name of the demantoid. Since the second half of the 1870s and until the 1950s, people called demantoids "chrysolites".

In 1896, Viktor Ivanovich Vorobyev, a student of St. Petersburg University, visited the placer of the Telyansky Klyuch. V. I. Vorobyev, the curator of the Mineralogical Department of the Geological Museum of the Imperial Academy of Sciences, made a statement at the meeting of the Mineralogical Society on April 2, 1902. The message was "On crystals of the demantoid from placers of the Telyansky Klyuch (Nizhny Tagil)". It said: "Wellformed demantoid crystals (called "chrysolite" in the Urals) from placers of the Telyansky Klyuch (Nizhny Tagil) are very rare. Only $P$. V. Eremeev speaks of them in the literature...." [17]. An indication of the belonging of the Nordensköld demantoids investigated by P. V. Eremeev in 1870 to the placer of the Telyansky Klyuch seems to have completely disallowed the question about the place where the demantoid was first found. Despite this, over the course of a century, many geologists have taken reported information about the Telyansky demantoid at the expense of the Bobrovsky deposit, apparently believing that the Telyansky occurrence and the Bobrovsky deposit are the same geological object but with different names that have changed over time.

Any doubts about the existence of the Telyansky occurrence of demantoids were dispelled at the present stage of the study of noble andradite deposits in the Urals. In 1996, Vladimir Anatolyevich Popov, the Ural mineralogist, in collaboration with A.A. Kanonerov, a well-known Ural mineral completist and expert on the surroundings of Nizhny Tagil, identified the following occurrences (deposits) of demantoids from north to south within the Tagil region: Telyansky, Bobrovsky, Zakharovsky, Zaitsev log, Sisimsky. At the same time, they noted that the sources of demantoids are located in the near-contact fracture zones of hyperbasite massifs from both the western and eastern sides [18].

The geological position of the Telyansky occurrence of demantoids

In geological terms, the Telyansky occurrence of demantoids is located in the middle part of the Vostochno-Tagilsky dunite-harzburgite massif in the Middle Urals. It is confined to the eastern contact of the massif with the intrusion of granites and plagiogranites of the Saldinsky anticlinorium (Fig. 3). The rocks of the site of occurrence are very diverse and represent a wide range of contact-metasomatic formations associated with a change in the shear zone and intense fracture of hyperbasites under the influence of granite intrusion.

In $2-2.8 \mathrm{~km}$ from the occurrence, closer to the axial part of the massif, serpentinites with relict harzburgite structure are dominated. In some areas, gray antigorite serpentinite develops along them. The latter is associated with the appearance of vein (along cracks) black and black-green magnetite-antigorite serpentinite. 


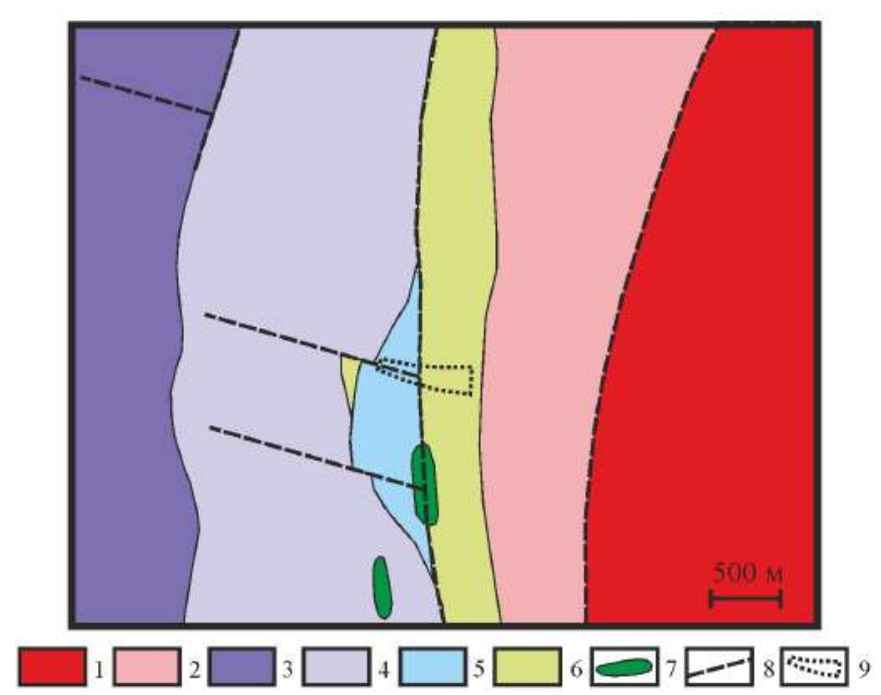

Figure 3. Geological and structural diagram of the Telyansky occurrennce of demantoids (compiled by the author). 1 - biotite granites, 2 - plagiogranites, 3 - apo-harzburgite antigorite serpentinites, 4 - recrystallized antigorite serpentinites, 5 - chloritized and talcitedserpentinites, 6 - amphibolites, 7 - plagioclasite bodies, 8 - tectonic disturbances, 8 -contour of the Telyansky placer.

Рисунок 3. Геолого-структурная схема Телянского проявления демантоидов (составлена автором). 1 - биотитовые граниты, 2 - плагиограниты, 3 - апо-гарцбургитовые антигоритовые серпентиниты, 4 - перекристаллизованные антигоритовые серпентиниты, 5 - хлоритизированные и оталькованные серпентиниты, 6 - амфиболиты, 7 - тела плагиоклазитов, 8 - тектонические нарушения, 8 - контур Телянской россыпи.

At the occurrence, you can find: recrystallized antigorite serpentinites; chloritized and talcited serpentinites turning into actinolite-talc shale; chloritized plagioclases; amphibolite plagioclasites; amphibolites; substantially muscovite and, less commonly, biotite plagiogranites. Exotic rocks include quartz porphyry found in placers both at the contact with plagiogranites and within the limits of the hyperbasite massif, with a base made of fine-grained feldspars and micro-lathlike blue alkaline amphibole.

Serpentinites are broken by three main crack systems. The first and earliest one has a north-northeastern strike $\left(17^{\circ}\right.$ on average) with a steep fall $-73^{\circ}$ to the southeast. The second system is located across the strike of the first one and extends with an average azimuth of $284^{\circ}$ and a steep northeast dip $-62^{\circ}$. Both fracture systems break serpentinites into boudines. A yellow-green ophite with polished surfaces develops along the cracks. The systems of superimposed cracks of predominantly sub-latitudinal strike form extended bands (from the first tens to hundreds of meters) of mylonitization and cleavage of the source rocks.

The latest third system of fissures with an average strike of $344^{\circ}$ and a gentle dip of $28^{\circ}$ to the south-west is a system of boudinage. The developmental bands of antigorite serpentinite are mainly associated with it, with the complete destruction of the relict structure of harzburgites and the formation of magnetite-antigorite serpentinite in the rims of serpentine-carbonate veins. In veins with an average thickness of $2 \mathrm{~cm}$, slip fibre brittle chrysotile asbestos (picrolite), calcite and aragonite are mainly developed.

Demantoids have not yet been found in the bed-rock occurrence. However, most likely, demantoid mineralization can be associated with the third system of fracturing in recrys- tallized antigorite serpentinites of the zone of contact of the massif with plagiogranites. The fusion of yellow and brownish-yellow andradites with chlorite indicates that garnet mineralization may also be present among the vein formations of the rodingite type in chloritized serpentinites.

Besides demantoids one can also find the following in the placer accumulation: magnetite and chrome spinelide in the form of octahedral crystals, epidote, amphibole, quartz, plagioclase and serpentine. In heavy mineral concentrates, native gold is constantly present.

The results obtained and their discussion

In the alluvial placer at the Telyansky occurrence, the author have found yellow and brownish-yellow andradites, as well as light yellow-green, green and bright green demantoids (Fig. 4). According to the form of separation, all found yellow and green garnets can be divided into three main groups: table-faced crystals, curved crystals, spherocrystal (spherulites).

In table-faced crystals, combinations of the rhombic dodecahedron with the tetragontrioctahedron and tetrahexahedron are observed. Moreover, the faces of the rhombic dodecahedron often prevail over all other forms. The typomorphism of garnet crystals of brownish-yellow color of the Telyansky occurrence often includes the complete development of the faces of the tetrahexahedron. The lustre of planes is from strong vitreous to brilliant. The presence of well-formed planes of a rhombic dodecahedron with brilliant lustre, and in some cases, well-developed, highly brilliant planes of a triangular tetrahexahedron with a high degree of transparency of crystals make small yellow and light green Telyansky andradites very similar to typical colored (yellow and green) Ural diamonds.

Spherulites are spherical and drop-shaped. They are often presented in the form of columnar, cylindrical, bunchy and irregularly shaped growths. Taking into account the fact that some spherulites are coated with serpentine, we can conclude that their almost perfect spherical shape is less related to the rounding of crystals in the placer, and is mainly a reflection of the growth mechanism of the spherocrystal. Among all the garnet grains, spherulites, as a rule, have a dull glass and waxy lustre. Unlike rhombic dodecahedral crystals, they often have the lowest degree of transparency.

The size of crystals of differently colored andradites varies from 0.1 to $8 \mathrm{~mm}$ and averages $0.5-1.5 \mathrm{~mm}$. The size of spherulites is from 0.1 to $10 \mathrm{~mm}$ in diameter, growths are up to $5 \times 15 \mathrm{~mm}$. The color of andradites is from brownish-brown, brownish-yellow and light yellow to light green and bright green. Bright green demantoids are rare. Mostly light yellow, light yellow-green and greenish differences are found.

Even the initial sampling of colored andradites from the placer of the Telyansky occurrence showed that they surprisingly correspond to the description of "Nordenskiöld's demantoids of 1870" according to their outward appearances (average size, shape of crystals and aggregates, color, degree of transparency). Their description given in 1902 is easily recognizable in well-formed brownish and yellow crystals of andradites. It is noteworthy that the first researchers of the Nordenskiöld's demantoids did not use the term "topazolite" at all. V. I. Vorobyev [17] calls yellowish-brown and greenish-yellow crystals of Telyansky andradites "demantoids". This assertion has its own logic. He well knew the description of the demantoids of N. G. Nordenskiöld from one of his teachers, Professor P. 
a

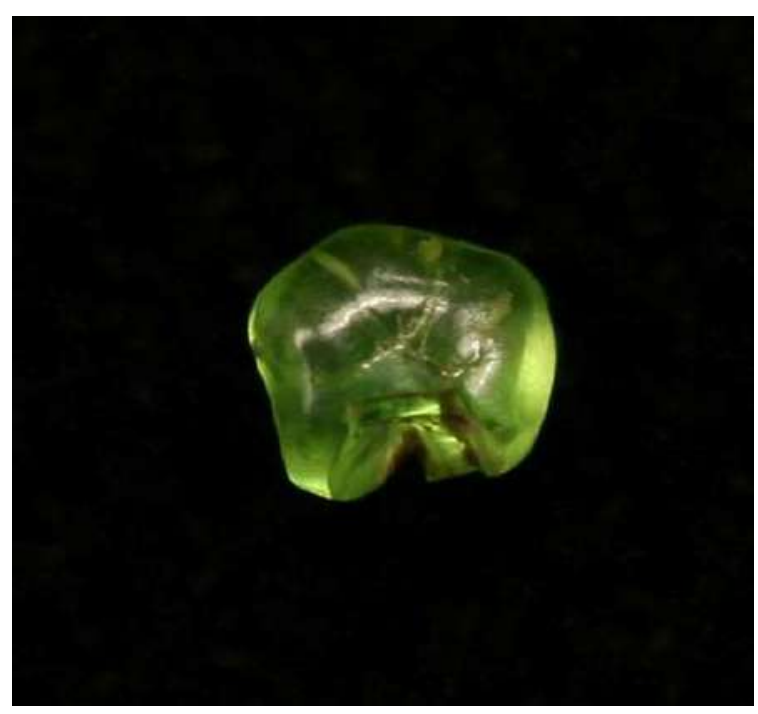

C

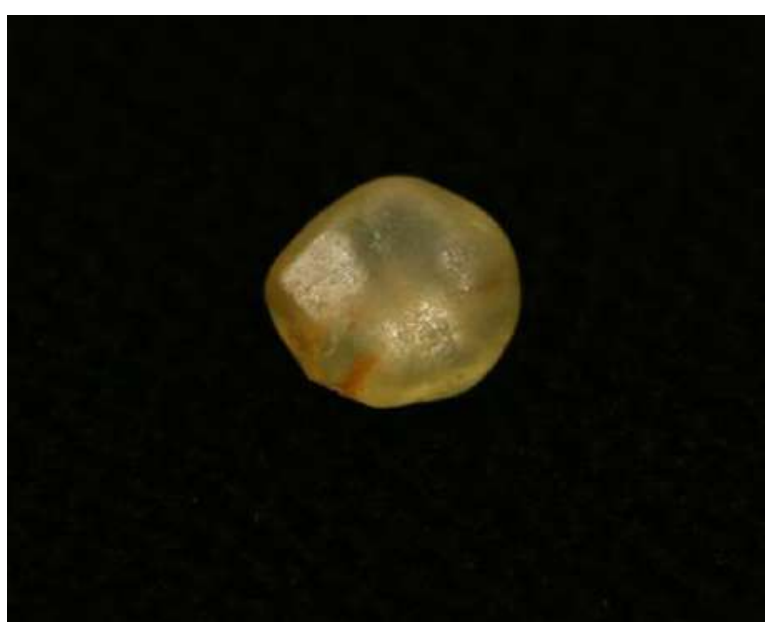

b

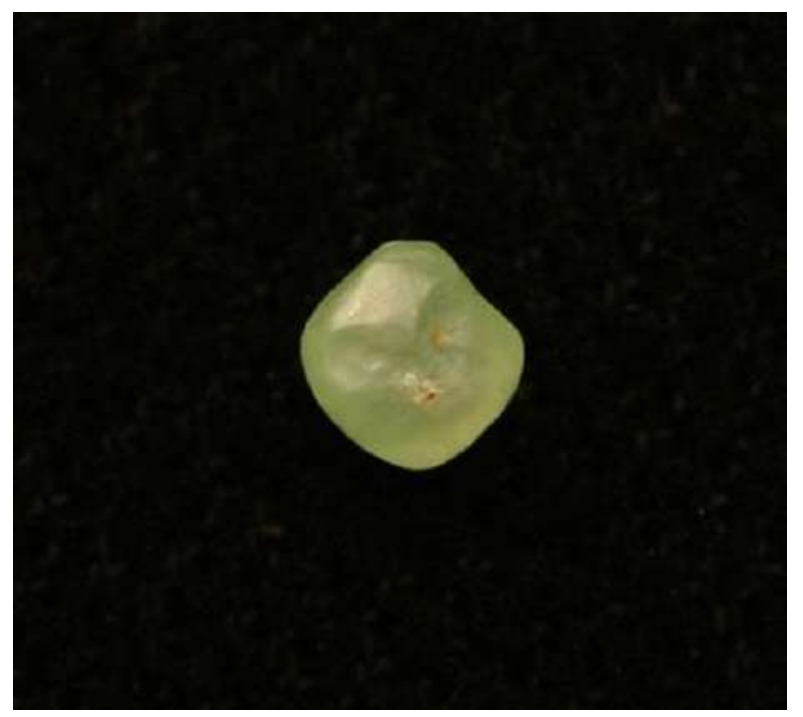

d

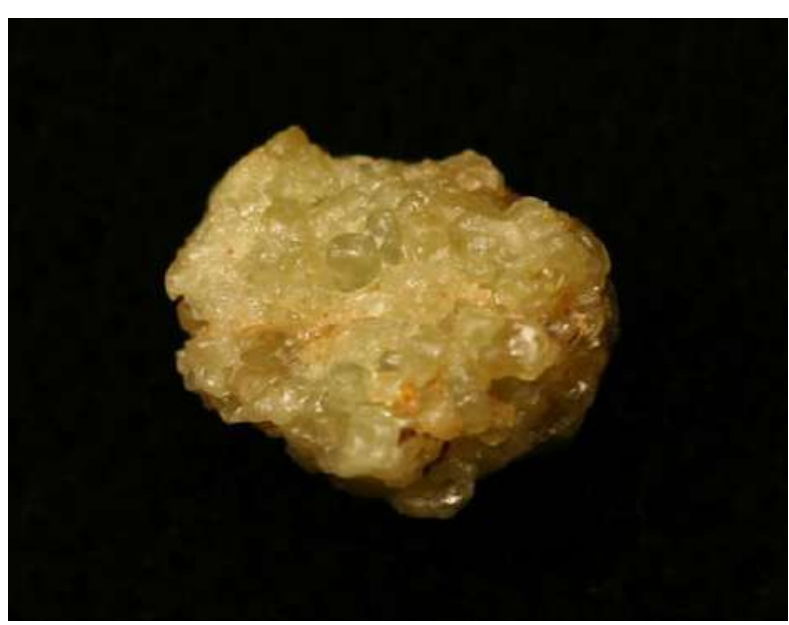

Figure 4. Demantoid from the placer of the Telyansky occurrence. Vostochno-Tagilsky Massif, Middle Urals. a - green crystal with a yellowish tint, size is $1.5 \times 1.8 \mathrm{~mm}$; b - light green crystal, size is $2.0 \times 2.0 \mathrm{~mm}$; c - crystal of light greenish-yellow color, size is $3.0 \times 3.0 \mathrm{~mm}$; $\mathrm{d}$ - granular aggregate of light greenish-yellow color, size is $7.0 \times 5.0 \mathrm{~mm}$. Author's photo.

Рисунок 4. Демантоид из россыпи Телянского проявления. Восточно-Тагильский массив, Средний Урал. а - кристалл зеленого цвета с желтоватым оттенком, размер 1,5 × 1,8 мм; б - кристалл светло-зеленого цвета, размер 2,0 × 2,0 мм; в - кристалл светлого зеленовато-желтого цвета, размер 3,0 × 3,0 мм; г - зернистый агрегат светлого зеленовато-желтого цвета, размер 7,0 $\times$ 5,0 мм. Фото автора.

V. Eremeev [14]. He was able to see "small individual grains, sometimes transparent and translucent, having brilliant lustre with different shades of yellow and green colors" - ideal demantoids of N. G. Nordenskiöld at the Geological Museum of the St. Petersburg Mining Institute, as well as in the collection of the Mineralogy office at St. Petersburg University.

Up until recently, the only complete chemical analysis of Nordenskiöld's demantoids from the Telyansky Klyuch carried out in 1881 by P. D. Nikolaev showed that they contain an abnormally high amount of aluminum for the demantoids of the Middle Urals (although these garnets are andradites) $-2.22 \% \mathrm{Al}_{2} \mathrm{O}_{3}$. Impurities of chromium in demantoids were not determined [13]. It must be emphasized that the laboratory assistant P. D. Nikolaev did not examine a single crystal or a certain color group of crystals. He investigated a combined sample of small crystals and rounded grains of Nordenskiöld's demantoids from different collections, which in different ratios included colored garnets of various morphological groups from yellowish brown to emerald green. We cannot exclude the possibility that a calcium aluminium garnet, a very common companion of the demantoid in the Ural placers, could be mixed here with a common sample of colored andradites. One way or another, the quantitative composition of individual varieties of Nordenskiöld's demantoids has remained unknown. The opportunity to fill this gap appeared only with the "new discovery" of the site of the first find of the demantoid in the Urals.

Modern microprobe analysis of individual crystals of demantoids of the Telyansky occurrence showed that garnets with different green color saturation are andradites with average contents according to the main components: $\mathrm{CaO}-33,18 \% ; \mathrm{Fe}_{2} \mathrm{O}_{3}-30,74 \% ; \mathrm{SiO}_{2}-35,02 \%$ (for 6 analyzes). The feature of the chemical composition of Telyansky demantoids is the absence or insignificant amount of aluminum im- 
Chemical composition of a demantoid form the Telyansky occurrence placer. Vostochno-Tagilsky massif, Middle Urals. Химический состав демантоида из россыпи Телянского проявления. Восточно-Тагильский массив, Средний Урал.

\begin{tabular}{ccccccccccc}
\hline $\begin{array}{c}\text { Analysis } \\
\text { number }\end{array}$ & $\mathrm{SiO}_{2}$ & $\mathrm{TiO}_{2}$ & $\mathrm{Al}_{2} \mathrm{O}_{3}$ & $\mathrm{Cr}_{2} \mathrm{O}_{3}$ & $\mathrm{Fe}_{2} \mathrm{O}_{3}$ & $\mathrm{MnO}$ & $\mathrm{MgO}$ & $\mathrm{CaO}$ & $\mathrm{Total}$ \\
\hline $1-1$ & 36.05 & 0.12 & 0.02 & 0.15 & 31.14 & 0.04 & 0.10 & 33.09 & 100.71 \\
$1-2$ & 34.73 & 0.07 & 0.00 & 0.50 & 29.97 & 0.00 & 0.05 & 33.30 & 98.62 \\
$2-1$ & 35.02 & 0.09 & 0.00 & 0.10 & 31.16 & 0.01 & 0.09 & 33.10 & 99.57 \\
$2-2$ & 34.70 & 0.05 & 0.01 & 0.37 & 30.96 & 0.07 & 0.07 & 33.08 & 99.31 \\
$3-1$ & 34.39 & 0.12 & 0.00 & 0.74 & 30.18 & 0.00 & 0.11 & 33.07 & 98.61 \\
$3-2$ & 35.23 & 0.04 & 0.00 & 0.02 & 31.03 & 0.00 & 0.04 & 33.43 & 99.79
\end{tabular}

Garnet formulas in terms of 8 cations

\begin{tabular}{cc}
$1-1$ & $\left(\mathrm{Ca}_{2.97} \mathrm{Mg}_{0.01}\right)_{2.98}\left(\mathrm{Fe}^{3+}{ }_{1.97} \mathrm{Cr}_{0.01} \mathrm{Ti}_{0.01}\right)_{1.99}\left[\mathrm{Si}_{3.03} \mathrm{O}_{12}\right]$ \\
$1-2$ & $\left(\mathrm{Ca}_{3.05} \mathrm{Mg}_{0.01}\right)_{3.06}\left(\mathrm{Fe}^{3+}{ }_{1.93} \mathrm{Cr}_{0.03} \mathrm{Ti}_{0.01}\right)_{1.97}\left[\mathrm{Si}_{2.97} \mathrm{O}_{12}\right]$ \\
$2-1$ & $\left(\mathrm{Ca}_{3.01} \mathrm{Mg}_{0.01}\right)_{3.02}\left(\mathrm{Fe}^{3+}{ }_{1.99} \mathrm{Cr}_{0.01} \mathrm{Ti}_{0.01}\right)_{2.01}\left[\mathrm{Si}_{2.97} \mathrm{O}_{12}\right]$ \\
$2-2$ & $\left(\mathrm{Ca}_{3.02} \mathrm{Mn}_{0.01} \mathrm{Mg}_{0.01}\right)_{3.04}\left(\mathrm{Fe}^{3+}{ }_{1.98} \mathrm{Cr}_{0.03}\right)_{2.01}\left[\mathrm{Si}_{2.95} \mathrm{O}_{12}\right]$ \\
$3-1$ & $\left(\mathrm{Ca}_{3.04} \mathrm{Mg}_{0.01}\right)_{3.05}\left(\mathrm{Fe}^{3+}{ }_{1.95} \mathrm{Cr}_{0.05} \mathrm{Ti}_{0.01}\right)_{2.01}\left[\mathrm{Si}_{2.94} \mathrm{O}_{12}\right]$ \\
$3-2$ & $\left(\mathrm{Ca}_{3.03} \mathrm{Mg}_{0.01}\right)_{3.04} \mathrm{Fe}^{3+}{ }_{1.98}\left[\mathrm{Si}_{2.98} \mathrm{O}_{12}\right]$ \\
\hline
\end{tabular}

Note: 1 - zoned colored demantoid (crystal fragment), a bright yellow-green center (an. 1-1) and a green edge (an. 1-2); 2 - yellowish-green demantoid (an. 2-1 - center, an. 2-2 - edge); 3 - zoned colored demantoid (whole crystal), a bright green center (an. 3-1) and a light green edge (an. 3-2). The analyzes were performed using the JXA-733 microanalyzer, Institute of Mineralogy, Ural Branch of the Russian Academy of Sciences, the analyst is E. I. Churin.

purity in them - not more than $0.02 \% \mathrm{Al}_{2} \mathrm{O}_{3}$, which is practically at the level of microprobe analysis sensitivity for this element. The amount of chromium varies from $0.02 \% \mathrm{Cr}_{2} \mathrm{O}_{3}$ in a light green demantoid to $0.5-0.74 \% \mathrm{Cr}_{2} \mathrm{O}_{3}$ in green and bright green andradites (table). In a bright green demantoid of early generation, chromium largely prevails over the total amount of other impurities. Typomorphism of the chemical composition of light yellow-green Telyansky demantoids is determined by the increased content of ferric iron in them at approximately equal proportions of small impurities of chromium and titanium. According to the crystal chemical formulas, Telyansky demantoids are low-impurity chromium-free and chromium-containing andradites. The similarly-named andradites of yellowish-green and light yellow-green color from the Verkh-Neivinsky massif of hyperbasites in the Middle Urals are the closest in composition to the Telyansky demantoids.

\section{Conclusions}

N. G. Nordenskiöld proposed the name for the demantoid at the turn of 1853-1854. He proposed the name not for jewelry stone, but for a mineral from the group of garnets, which in its properties was very different from uvarovite and from all varieties of calcium aluminium garnets of yellow and green colour, including topazolite, which was identified with calcium aluminium garnet at that time. This happened before the term "andradite" was proposed by D. D. Dana in 1868. The main meaning that N. G. Nordenskiöld put in the name of the de- mantoid is a brilliant lustre and the shape of garnet crystals with a predominance of rhombic dodecahedron. The belonging of Nordenskiöld's demantoids to andradite was first determined by P. V. Eremeev in 1879. Demantoids included all color varieties of andradite with a bright lustre from brownish yellow, yellow, greenish yellow, yellowish green, green and emerald green. The original name of "diamond-like garnet" of N. G. Nordenskiöld has a German root and is read as Diamantoite. Over time, it was transformed first into the Demantoite, and then into the Demantoid already familiar to everyone. Modern analysis shows that the green differences of Nordenskiöld's demantoid are weakly chromium and chromium-containing andradites. The main feature of the chemical composition of an ideal Ural demantoid is the absence of an impurity of a grossularite minal.

The place of the first find of low-impurity and chromium-containing andradites in the Urals with the name of "diamantoite" by Nordenskiöld is the Telyansky occurrence in the Vostochno-Tagilsky dunite-harzburgite massif in the Middle Urals. The degree of geological exploration of the Telyansky occurrence remains extremely low. Based on the initial heavy mineral sand sampling we can conclude that the Telyansky occurrence is not able to compete with the Poldnevskoye and Bobrovskoye deposits in the Middle Urals by the amount of jewelry crystal raw materials of demantoids. Commercial interest here can be associated with the integrated extraction of demantoids from the placer along with gold.

The work was performed within the State assignment of the Zavaritsky Institute of Geology and Geochemistry of the Ural Branch of the Russian Academy of Sciences, the number is AAAA-A18-118052590032-6. 


\section{REFERENCES}

1. Alexandrov A. I. 1975, Demantoid is chromium-containing andradite from the lizavetinskaya Bobrovka (Middle Urals). Mineralogiya $i$ petrografiya Urala [Mineralogy and petrography of the Urals], issue 106, pp. 140-145. (In Russ.)

2. Koltovsky G. 1858, Mines and placers in the district of Nizhny Tagil factories of Demidovs. Gorniy zhurnal [Mining Journal], vol.1, p. 3, pp. 218-282. (In Russ.)

3. O dobyche "khrizolitov» (demantoidov) na Pavlovskom priiske (Nizhniy Tagil) v 1893-1896 [On the production of "chrysolites" (demantoids) in the Pavlovsky mine (Nizhny Tagil) in 1893-1896]. State archive of the Sverdlovsk region, Nizhny Tagil branch. F. 10. Inv. 5. Item 2010, 2136.

4. Schriften der in St. 1842, Petersburg gestifteten Russisch-Kaiserlichen Gesellschaft fur die Gesammte Minerallogie. Band I. Abtheilung I. St. Petersburg. S. CXXXI-CXXXVI.

5. Avdonin V. N., Polenov Yu. A. 2002, Ocherki ob ural'skikh mineralakh [Essays on the Ural minerals]. Ekaterinburg, 411 p.

6. Betekhtin A. G. 1946, O khromovykh granatakh iz Nizhne-Tagil'skogo dunitovogo massiva [About chrome garnets from the Nizhne-Tagil dunite massif]. For the academician Dmitry Stepanovich Belyankin on the occasion of the 70th birthday and 45th anniversary of scientific activity: collection of papers. Moscow, pp. 68-73.

7. Ganzha S. 1996, Nordenskiöld in the Urals. Tagil'skiy rabochiy [Tagil worker], no. 93-94, p. 4. (In Russ.)

8. Waller J. Analys af Demantoid från Ural. Geologiska Föreningen i Stockholm Förhandlingar. Fjerde Bandet. Stockholm (Argangarne 1878 och 1879). S. $184-187$.

9. Nefediev V. V. 1871, Condensed catalogue of the mineralogical collection of the Museum of the Mining Institute. Saint-Petersburg.

10. Dana J. D. 1904, System of Mineralogy. Descriptive Mineralogy. Edition 4. N. Y.; London, pp. 190-194.

11. Golynskaya O. A., Svirina E. S. 1997, Pages of the history of mineralogy: Nils Gustaf Nordenskiöld; 1792-1866. Mir kamnya [World of stones], no 12, pp. 17-22. (In Russ.)

12. Planer D. 1867, Collection of newly discovered and newly explored minerals in recent times. Gorniy zhurnal [Mining Journal], p. II, pp. 390. (In Russ.)

13. Nikolaev P. D. 1881, Analytical works. Gorniy zhurnal [Mining Journal], vol. II, p. 378. (In Russ.)

14. Eremeev P. V. 1871, About the demantoid of N. Nordenskiöld from the placers near the Nizhne-Tagil plant in the Urals. Zapiski RMO [Proceedings of the Russian Mineralogical Society]. The second series, p. 6, pp. 391-393. (In Russ.)

15. Eremeev P. V. 1880, About the demantoid from the vicinity of Nizhny Tagil in the Urals. Zapiski RMO [Proceedings of the Russian Mineralogical Society]. The second series, p. 15, p. 207 (In Russ.)

16. Dana E. S. 1904, System of Mineralogy. Descriptive Mineralogy. Edition 6. N. Y.; London, pp. 439-448.

17. Vorobyev V. I. 1903, Message on demantoid crystals from the placers of the Telyansky Klyuch (Nizhny Tagil). Zapiski RMO [Proceedings of the Russian Mineralogical Society]. The second series, p. 40, pp. 72-73. (In Russ.)

18. Popov V. A., Kanonerov A. A. 1996, Ural'skaya provintsiya demantoidov [Ural province of demantoids], lecture notes of the Mineralogical Society of the Russian Academy of Sciences. Saint-Petersburg, p. 27. 


\title{
Аемантоид из Телянского Киюча (Средний Ураи) - место пер- вой
}

\author{
находки на Урале
}

\section{Сергей Юрьевич КРОПАНЦЕВ ${ }^{12^{*}}$}

${ }^{1} \mathrm{OOO} \mathrm{«Березовский} \mathrm{рудник»,} \mathrm{Березовский} \mathrm{Свердловской} \mathrm{обл.,} \mathrm{Россия}$

${ }^{2}$ Институт геологии и геохимии им. акад. А. Н. Заварицкого УрО РАН, Россия, Екатеринбург

\section{Аннотация}

Актуальность работы обусловлена необходимостью изучения уральских драгоценных камней, в том числе и открытых на Урале. Это важно не только с научной точки зрения, но и для истории науки и для развития геотуризма в нашем регионе.

Цель работь: исследование химического состава демантоида с Телянского Ключа, который является местом первой находки данного драгоценного камня на Урале.

Методология исследования. Демантоид (ювелирный андрадит зеленого цвета) был намыт автором в золотоносной россыпи Телянского Ключа, количественный анализ химического состава граната выполнен на рентгеноспектральном электронно-зондовом микроанализаторе JXA-733.

Pезультаты. Проведено историческое исследование мест находок демантоидов на Среднем Урале и установлено, что впервые драгоценный гранат был обнаружен не в россыпях р. Бобровки, расположенной южнее г. Нижний Тагил, а севернее этого города, в золотоносной россыпи Телянского Ключа. Микрозондовый анализ отдельных кристаллов демантоидов показал, что гранаты с разной насыщенностью зеленой окраски по основным компонентам являются андрадитами со средними содержаниями: $\mathrm{CaO}-33,18 \%$; $\mathrm{Fe}_{2} \mathrm{O}_{3}-30,74$ $\% ; \mathrm{SiO}_{2}-35,02$ \% (для 6 анализов). Особенностью химического состава телянских демантоидов является отсутствие или ничтожное количество в них примеси алюминия - не более 0,02 \% $\mathrm{Al}_{2} \mathrm{O}_{3}$, что практически на уровне чувствительности микрозондового анализа для данного элемента. Количество хрома варьирует от 0,02 $\% \mathrm{Cr}_{2} \mathrm{O}_{3}$ в светло-зеленом демантоиде до 0,5-0,74 \% $\mathrm{Cr}_{2} \mathrm{O}_{3}$ в зеленых и ярко-зеленых андрадитах.

Bbьводы. Местом первой находки малопримесного и хромсодержащего андрадитов на Урале с впервые предложенным для них Н. Г. Норденшельдом названием - «диамантоит» является золотоносная россыпь Телянского Ключа на Восточно-Тагильском дунит-гарцбургитовом массиве на Среднем Урале.

Ключевые слова: гранат, андрадит, демантоид, серпентиниты, Телянский Ключ, Средний Урал.

\section{ЛИТЕРАТУРА}

1. Александров А. И. Демантоид - хромсодержащий андрадит из Елизаветинской Бобровки (Средний Урал) // Минералогия и петрографрия Урала. 1975. Вып. 106. С. 140-145.

2. Колтовский Г. Рудники и прииски в округе Нижне-Тагильских заводов гг. Демидовых // Горный журнал. 1858. Т. 1. Ч. 3. С. 218-282.

3. О добыче «хризолитов» (демантоидов) на Павловском прииске (Нижний Тагил) в 1893-1896 гг. // Государств. архив Свердловской области, Нижнетагильское отделение. Ф. 10. Оп. 5. Ед. хр. 2010, 2136.

4. Schriften der in St. Petersburg gestifteten Russisch-Kaiserlichen Gesellschaft fur die Gesammte Minerallogie. Band I. Abtheilung I. St. Petersburg. 1842. S. CXXXI-CXXXVI.

5. Авдонин В. Н., Поленов Ю. А. Очерки об уральских минералах. Екатеринбург: УГГГА, 2002. 411 с.

6. Бетехтин А. Г. О хромовых гранатах из Нижне-Тагильского дунитового массива // Академику Дмитрию Степановичу Белянкину к 70-летию со дня рождения и 45-летию научной деятельности: сборник статей. М.: АН СССР, 1946. С. 68-73.

7. Ганьжа С. Норденшельды на Урале // Тагильский рабочий. 1996. № 93-94. С. 4.

8. Waller J. Analys af Demantoid från Ural // Geologiska Föreningen i Stockholm Förhandlingar. Fjerde Bandet. Stockholm (Argangarne 1878 och 1879). S. $184-187$.

9. Нефедьев В. В. Краткий каталог минералогического собрания Музеума Горного института. С.-Пб. 1871.

10. Dana J. D. System of Mineralogy. Descriptive Mineralogy. Edition 4. New York; London, 1854. P. 190-194.

11. Голынская О. А., Свирина Е. С. Страницы истории минералогии: Нильс Густаф Норденшельд (Nils Gustaf Nordenskiöld; 1792-1866) // Мир камня. 1997. № 12. С. 17-22.

12. Планер Д. Сборник вновь открытых и вновь исследованных в новейшее время минералов // Горный журнал. 1867. Ч. II. С. 390.

13. Николаев П. Д. Аналитические работы // Горный журнал. 1881. Т. ІІ. С. 378.

14. Еремеев П. В. О демантоиде Н. Норденшельда из россыпей около Нижне-Тагильского завода на Урале // Записки Императорского Минералогического общества. 1871. Вторая серия. Ч. 6. С. 391-393.

15. Еремеев П. В. О демантоиде из окрестностей Нижнего Тагила на Урале // Записки Императорского Минералогического общества, 1880. Вторая серия. Ч. 15. С. 207.

16. Dana E. S. System of Mineralogy. Descriptive Mineralogy. Edition 6. New York; London, 1904. P. 439-448.

17. Воробьев В. И. Сообщение о кристаллах демантоида из россыпей Телянского Ключа (Нижний Тагил) // Записки Императорского Минералогического общества. 1903. Вторая серия. Ч. 40. С. 72-73.

18. Попов В. А., Канонеров А. А. Уральская провинция демантоидов // Тез. докл. Минералог. об-ва РАН. СПб.: СПбГИ, 1996. С. 27.

Статья поступила в редакцию 10 декабря 2019 года

kropantsev@mail.ru

ORCID ID 0000-0002-4373-4261 